DOI 10.37882/2223-2982.2021.03-2.03

\title{
ОСОБЕННОСТИ АМЕРИКАНСКОЙ ОТРАСЛЕВОЙ ЛЕКСИКОГРАФИИ (НА ПРИМЕРЕ ВОЕННЫХ ПЕРЕВОДНЫХ СЛОВАРЕЙ)
}

\section{AMERICAN SPECIALIZED LEXICOGRAPHY (BASED ON MILITARY BILINGUAL DICTIONARIES)}

\section{Balkanov}

Summary: This article studies into the specifics of military translation, or bilingual, dictionaries published in the United States of America within the Military Dictionary Project in the XX century. It analyzes and summarizes the experience accumulated in the field of specialized (military) lexicography, investigates the structure of the military dictionaries, provides their comparative analysis. The research should be considered relevant as it probes into the issues related to the current state of theoretical and practical specialized lexicography, including military lexicography, summarizes the specifics of the structure of American military bilingual dictionaries, and considers their application by military translators and interpreters.

Keywords: translation dictionary, military vocabulary, military terminology, bilingual lexicography, minimal dictionary, microstructure of electronic illustrated translation dictionary.
$\mathrm{H}$ а Западе попытки глубокого изучения и систематизации структуры двуязычных словарей были предприняты в первой половине XIX века: основное внимание тогда сосредоточилось на исследовании англо-латинских словарей эпохи Средневековья. В дальнейшем на протяжении всего XIX века наблюдается тенденция к увеличению интереса ученых к изучению теоретических аспектов составления переводных словарей. Британские и американские лингвисты, в числе которых А. Вэй и А. Мэйхью, закладывают основы анализа мега-, макро- и микроструктуры, результатом чего стали первые работы в области теоретической двуязычной лексикографии. А уже во второй половине XX века в научных работах советского лексикографа Л.В. Щербы были заложены основы теоретической лексикографии как самостоятельной научной дисциплины.

С развитием компьютерных и информационных технологий представление о теоретической и практической лексикографии в очередной раз изменилось. Современные двуязычные, или переводные, словари создаются на единой платформе и представляют собой сочетание общих и отраслевых (специальных) словарей, а также толковых словарей и словарей лексической сочетаемости
Балканов Илья Владимирович

К.ф.н., дочент, Военный университет Министерства обороны Российской Федерации, Москва

i-balkanov@mail.ru

Аннотация: Данная статья посвящена исследованию особенностей военных переводных словарей, изданных в (ША в рамках проекта «Military Dictionary Project». Целями исследования стали анализ и обобщение накопленного опыта по отраслевой (военной) лексикографии, изучение особенностей структуры данных военных словарей, их сравнительно-сопоставительный анализ. Выбранную тему следует считать актуальной, поскольку она затрагивает вопросы, связанные с текущим состоянием теоретической и практической отраслевой, в том числе военной, лексикографии, обобщает особенности структуры американских военных переводных словарей, раскрывает особенности их применения в практической деятельности военного переводчика.

Ключевые слова: переводной словарь, военная лексика, военная терминология, двуязычная лексикография, словарь-минимум, микроструктура электронного иллюстрированного переводного словаря.

как входного языка, так и выходного языка. При этом основными задачами словаря остаются «упорядочивание слов по различным категориям, описание значений слов и их принадлежности к различным частям речи, транскрибирование» [1; с. 19].

Однако практическая лексикография значительно опережает теоретическую, что обуславливает необходимость проведения сравнительно-исторического и сопоставительного анализа общих и отраслевых переводных словарей в целях обобщения накопленного опыта и изучения путей и подходов к составлению словарей, предложенных лексикографами разных стран.

Целью нашего исследования является рассмотрение особенностей структуры традиционных, или бумажных, и электронных отраслевых (военных) переводных словарей, выпущенных в США в XX веке.

Вопросом изучения военных переводных словарей занимались многие известные лексикологи и лексикографы. Среди них одной из самых значимых фигур был Г.А. Судзиловский, который «посвятил себя изучению военной лексики и описанию ее особенностей, что при- 
вело к созданию фундаментальных трудов в области составления общих и специальных словарей» [2, с. 37]. В своих трудах он предлагал разделить военную лексику на эмоционально окрашенные элементы военной лексики и военную терминологию [3, с. 1012]. При этом военная терминология представляет собой «пласт лексики, используемой в военной сфере для обозначения вооружения и военной техники, оперативно-тактических и боевых действий и другого рода понятий, имеющих отношения к военной сфере» [4, с. 34], а эмоционально окрашенные элементы военной лексики «являются в большинстве случаев стилистическими синонимами соответствующих военных терминов» [5, с. 104].

Ниже приведены примеры использования эмоционально окрашенной лексики в военных переводных словарях:

- rookie разг. новичок, новобранец

- brass разг. офицеры

Начало XX века ознаменовалась большими социально политическими потрясениями, следствием которых стали многочисленные военные конфликты и революционные движения. Изменения в тактике ведения как оборонительных, так и наступательных действий, создание новых видов вооружений и военной техники, усиление роли допросов и растущей значимости разведывательных сведений, потребовал от лексикографов вносить изменения в уже существующие словари и составлять новые.

В СССР в первой половине XX века военная двуязычная лексикография развивалась усилиями выдающегося лексикографа А.М. Таубе, который занимался составлением различных переводных военных словарей (немецко-русских, англо-русских и французско-русских).

В то же время минобороны США начинает проект «Military Dictionary Project», в рамках которого реализуется программа создания переводных словарей, с помощью которых американские военнослужащие могли бы взаимодействовать с представителями других стран и национальностей, в том числе во время ведения боевых действий.

За время Второй мировой войны лексикографы проекта «Military Dictionary Project» выпускают и впоследствии переиздают следующие словари:

- TM 30-254 Military Dictionary (военный англо-русский и русско-английский словарь 1941 г.);

- ТM 30-257 Military Dictionary (военный англо-португальский и португальско-английский словарь 1941 г.);

- TM 30-259 Military Dictionary (военный англо-итальянский и итальянско-английский словарь 1942 г.);

- TM 30-255 Military Dictionary (военный англо-не- мецкий и немецко-английский словарь 1941 г.);

- TM 30-250 Military Dictionary (военный англо-испанский и испано-английский словарь 1941 г.);

- TM 30-253 Military Dictionary (военный англофранцузский и французско-английский словарь 1943 г.);

- тM 30-541 Military Dictionary (военный англо-японский и японско-английский словарь 1944 г.);

- TM 30-533 Military Dictionary (военный англо-китайский и китайско-английский словарь 1944 г.).

Кроме того, в годы Войны были выпущены «разговорники и справочники по многим европейским (сербохорватскому, исландскому, венгерскому, румынскому), ближневосточным (марокканскому, арабскому), азиатским (вьетнамскому, малайскому, кхмерскому) и другим редким языкам» [6, с. 115].

Так, англо-итальянский словарь ТМ 30-259 Italian Military Dictionary 1943 года был разработан в связи с подготовкой США к ведению боевых действий на территории Апеннинского полуострова. В мегаструктуре данного словаря, как и всех других словарей проекта «Military Dictionary Project», можно выделить краткую вводную часть, словником и приложения-списки. При этом словник делится на итальянско-английский и англо-итальянский словари и словарь сокращений. Англоитальянская часть словника состоит из 6500 терминов, а итальянско-английская - 7 000. Аналогичную структуру имеет и англо-немецкий военный словарь ТМ 30-506 German Military Dictionary, который вышел в 1944 году незадолго до высадки союзников в Нормандии тиражом в несколько тысяч экземпляров. Данный словарь представляет собой дополненную и расширенную версию словаря ТМ 30-255 German Military Dictionary, вышедшего в 1941 году.

Вторая половина XX века ознаменовалась усилениями научно-технического прогресса, информатизацией общества и целым рядом социально- политических потрясений, следствием которых стал переход от многополярного мира к однополярному. Создание новых видов вооружений и военной техники, изменения в стратегии и тактике ведения боевых действий потребовали от лексикографов вносить изменения в уже существующие словари и составлять новые.

В США развитие двуязычной лексикографии активно продолжилось и в послевоенный период. В ходе реализации программы помощи странам Европы, или «Плана Маршала», появилась острая необходимость в переводчиках, в том числе военных. Для обучения такого рода специалистов министерство обороны продолжает проект создания военных словарей. Создаваемые переводные словари отличаются друг от друга мега-, макро- и микроструктурой и требуют более тщательного анализа. 
Англо-вьетнамский словарь 1969 года был разработан в связи с началом войны во Вьетнаме. Он представляет собой переводной словарь-разговорник для военнослужащих армии США, участвующих в работе с переводной документацией и допросах военнопленных. В предваряющих текстах содержатся правила пользования словарем и дается краткое пояснение того, как данный словарь должен помочь военнослужащему в выполнении возложенных на него обязанностей. Корпус словаря делится на уже привычные для проекта военных словарей четыре раздела: англо-вьетнамский словарь, вьетнамо-английский словарь, условные обозначения и сокращения, приложения. Вокабулы расположены в начально-алфавитном (прямом) порядке. В словарных статьях используются стилистические пометы разговорного толка: США учувствуют в гражданской войне и борются с группировками повстанцев. В целом данный военный словарь ориентирован на специалиста в области военного перевода, который является носителем английского языка, что находит отражение в предельно простой структуре словарной статьи, когда эквиваленты приводятся в правой части после специального знака (__ $)$ :

personnel (n) _ _ nhân viên, cán bộ, nhân sự napalm bombs $(n)$ __ bom napan

Необходимость существования другого словаря Проекта, англо-персидского словаря 1971 года, обусловлена нарастанием напряжения в отношениях США и Ирана. Данный словарь является двухтомным изданием на 60 000 лемм. В словарных статьях присутствуют фразеологические единицы, продемонстрировано стилистическое расслоение лексики персидского языка. В словник помещены военные термины, встречающиеся в боевых уставах и документах (warplane "موشك مایهو اب" и engine "موتخـور"). Экстралингвистическую информацию можно получить из приложений и помет, которые отражают сферу применения, стилистическую окраску и культурные реалии. Приложения содержат сравнительную и описательную информацию о воинских званиях в вооруженных силах государства Иран.

Необходимость существования англо-дари словаря 1986 года обусловлена активным участием США в событиях в Афганистане. В рамках помощи различным группировкам Афганистана и поставок им оружия требовалось качественное знание языков народов Афганистана, одним из которых является дари. Именно для этих целей министерством обороны был разработан англо-дари военный и технический словарь, который содержит около 40000 словарных статей и охватывает наиболее употребительную и устоявшуюся военную терминологию дари по всем видам вооруженных сил, устройству и эксплуатации различной военной техники, управлению войсками и их боевому применению, прохождению военной службы, организации быта и жизни военнослужащего. В конце словаря даются: основные географические назва- ния; команды и формы докладов; условные сокращения, применяемые в боевых и служебных документах; таблица воинских званий; календари - солнечный хиджры и европейский. При составлении словаря использовались афганские полевые наставления, руководства и пособия по устройству и эксплуатации военной техники.

Словарь построен по алфавитно-гнездовой системе. Составные термины находятся в гнезде основного определяемого слова. Основной термин в гнезде заменяется знаком тильдой « », которая ставится на первое место. Факультативная часть заключена в круглые скобки:

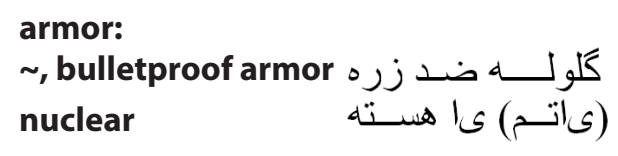

В заключительных разделах приводятся некоторые афганские заимствования и список условных сокращений, применяемых в боевых документах и переписке афганских военных. Например:

В заключительных разделах приводятся некоторые афганские заимствования и список условных сокращений, применяемых в боевых документах и переписке афганских военных. Например:

section:

short: ن full: بخـشـ

Данный словарь предназначен для переводчиков и специалистов в области военной терминологии Афганистана и может быть использован в качестве разговорника в тех случаях, когда нужно в течение короткого времени дать правильный перевод или пояснение адресату.

Развитие военной науки происходило на всех этапах развития общества. Происходило появление новых родов войск и видов вооруженных сил, систем вооружения, тактик и стратегии ведения боевых действий. Все это приводило к созданию огромного количества специальных военных лексически единиц, которые должны были быть систематизированы, в том числе в двуязычных военных словарях.

Все изученные нами словари имеют типовую мега-, макро- и микроструктуру и выполняют функцию подбора эквивалентов для дальнейшего их использования пользователем в процессе перевода и лингвистического обеспечения военной деятельности. Проект Military Dictionary Project позволил американским военным на протяжении всего XX века отвечать на постоянно растущие потребности армии и флота в военных переводчиках, успевать отслеживать изменения в военной сфере, накапливать и передавать опыт создания военных переводных словарей, которые в условиях XXI века - века цифровых технологий - предстоит представить в новом электронном формате. 


\section{ЛИТЕРАТУРА}

1. Щерба, Л.В. Языковая система и речевая деятельность / Л. В. Щерба. - Л.: Наука, 1974

2. Балканов, И.В. Теоретические аспекты двуязычной лексикографии (на материале военных переводных словарей): дис. .... канд. филол. наук: 10.02 .20 / И.В. Балканов. - М., 2017. - 194 с.

3. Англо-русский военный словарь: ок. 50000 терминов / под общ. ред. Г.А. Судзиловского. - М.: Воениздат, 1968. - 1064 с.

4. Шевчук, В.Н. Военно-терминологическая система в статике и динамике: автореф. дис. ... д-ра филол. наук: 10. 02.19 / В. Н. Шевчук. - М., 1985. - 43 С.

5. Судзиловский, Г.А. Сленг - что это такое? / Г.А. Судзиловский. - М.: Воениздат, 1973. - 182 с.

6. Балканов, И.В. Теория и практика зарубежной военной лексикографии периода второй мировой войны (на материале военных переводных словарей, выпущенных в (ША в 1941-45 гг.) / И.В. Балканов // Политическая лингвистика. - 2016. - № 2. - С. 112 - 117.

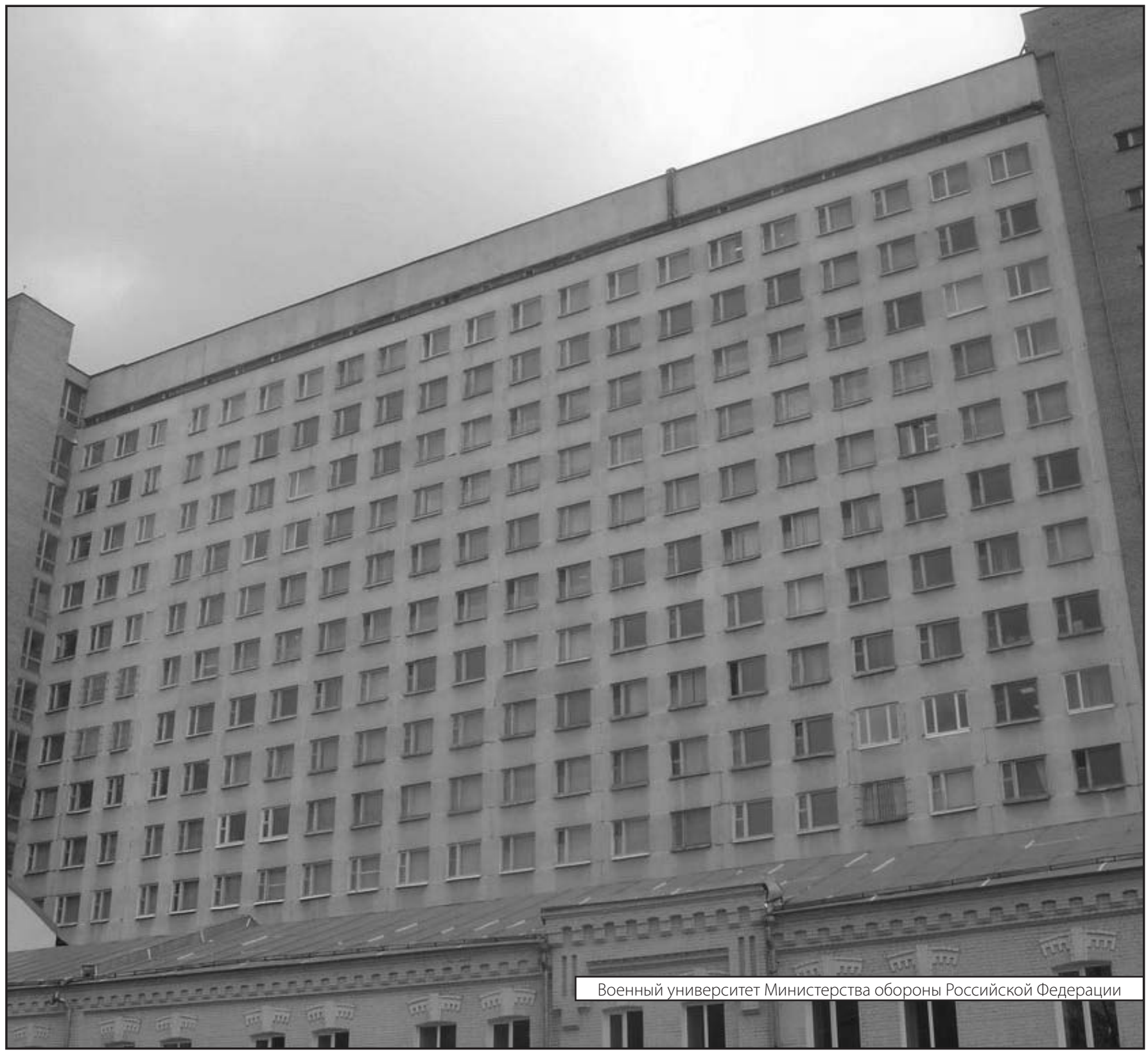

